\title{
KINERJA MANAJEMEN SUMBER DAYA MANUSIA DI ERA DISRUPSI
}

\author{
Rustandi \\ STIA YPPT Priatim Tasikmalaya \\ Kota Tasikmalaya, Jawa Barat, Indonesia \\ rustandi@stia-tasik.ac.id
}

\begin{abstract}
ABSTRAK
Saat ini tuntutan untuk melakukan perubahan dan penyesuaian yang dilakukan oleh berbagai kalangan organisasi publik maupun bisnis semakin komplek, dinamis dan dihadapkan pada berbagai ketidakpastian lingkungan. Keadaan ini menuntut organisasi harus berkompetisi untuk bisa menang, melakukan inovasi yang beyond-disruption, menciptakan pasar baru tanpa perlu bersaing dengan yang sudah ada, tanpa harus mengalahkan siapapun. Mensikapi segala perubahan dan permasalahan yang terjadi saat ini memang tidak mudah, tetapi faktor determinannya adalah organisasi berusaha untuk membangun kinerja manajemen sumber daya manusia. Karena permasalahan kinerja manajemen sumber daya manusia merupakan permasalahan internal organisasi, hal ini memerlukan perubahan dan mutlak dilakukan dalam rangka mengantisipasi terhadap perubahan yang dilakukan organisasi untuk berkompetisi serta berinovasi sehingga menuntut bersikap profesonal, cepat dan responsif dalam memberikan pelayanan kepada masyarakat. Untuk meningkatkan kredibilitas organisasi diperlukan perspektif baru dalam mengelola kinerja sumber daya manusia, seperti organisasi menyelenggarakan diklat diarahkan untuk meningkatkan keahlian dan kecakapan pegawai yang memberikan pemahaman dan penguasaan kompeteni di bidang informasi teknologi, hal ini penting untuk mendukung pelaksanaan tugas-tugas SDM dimasa mendatang.
\end{abstract}

Kata Kunci: Kinerja organisasi, Manajemen SDM, dan Era Disrupsi.
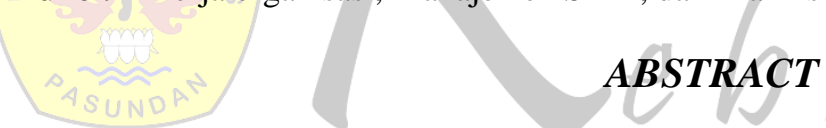

Currently, the demands for changes and adjustments made by various circles of public and business organizations are increasingly complex, dynamic and are faced with various environmental uncertainties. This situation requires organizations to compete to win, to make innovations beyond disruption, to create new markets without having to compete with existing ones, without having to beat anyone. Responding to all changes and problems that occur today is not easy, but the determinant factor is the organization trying to build human resource management performance. Because the problem of human resource management performance is an internal organizational problem, this requires change and is absolutely necessary in order to anticipate changes made by the organization to compete and innovate so that it demands professional, fast and responsive behavior in providing services to the community. To increase the credibility of the organization, a new perspective is needed in managing the performance of human resources, such as the organization organizing education and training aimed at increasing the expertise and skills of employees who provide understanding and mastery of competents in the field of information technology, this is important to support the implementation of HR tasks in the future.

Keywords: Organizational Performance, HR management, and The Era of Disruption.

\section{PENDAHULUAN}

Mengingat pentingnya menghadapi fenomena " era disrupsi (disruption)“, situasi dimana pergerakan dunia industri atau persaingan kerja tidak lagi linier, perubahannya sangata cepat dan fundamental serta berusaha untuk menciptakan tatanan baru, menginsiasi lahir bisnis baru dengan strategi lebbih inovaif dan disruptif, cakupannya luas mulai dari dunia bisnis, pebankan, transfortasi, sosial masyarakat sampai pendidikan, maka jelas bahwa semua (yang dibuat) oleh organisasi pemerintah dalam menata dan menyelenggarakan birokrasi pemerintahan lebih diarahkan kepada 
upaya atau pendekatan strategik dan koheren untuk mengelola aset paling berharga milik organisasi atau orang-orang yang bekerja di dalam organisasi, baik secara individu ataupun kolektif, memberikan sumbangan untuk mencapai sasaran organisasi. Pendekatan strategik dan koheren untuk mengelola aset paling berharga milik organisasi lebih dipokuskan dalam melakukan pekerjaan dan hasil yang dicapai dari pekerjaan itu, antara lain menyangkut ; pengelolaan sumber daya manusia yang rasional, menghargai manusia sebagai modal dimana dari mereka akan diperoleh hasil dengan melakukan investasi untuk pengembangannya, termasuk sumber keunggulan kompetitif melalui komitmen, kemampuan beradaptasi dan kualitas tinggi. Peran dan tanggungjawab untuk melaksanakan pendekatan strategik dan koheren dalam mengelola aset paling beharga milik organisasi di era disrupsi adalah organisasi pemerintah. Organisasi pemerintah dalam melakukan penataan sumber daya manusia masih dihadapkan pada permasalahan yakni ; “ (1) kelembagaan birokrasi pemerintah yang besar dan didukung oleh sumber daya aparatur yang kurang profesional, (2) mekanisme kerja yang sentralistik masih mewarnai kinerja birokrasi pemerintah, (3) kontrol terhadap biokrasi pemerintah masih dilakkan oleh pemerintah, untuk pemerintah dan dari pemerintah, (4) patronkline $(\mathrm{KKN})$ dalam birokrasi pemerintah merupakan halapangan terhadap upaya mewujudkan merirokrasi dalam birokrasi, (\%) tidak jelas dan bahkan cenderung tidak ada sense of accountability baik secara kelembagaan maupun individu, (6) jabatan birokrasi yang hanya menampung jabaan struktural dan pengisiannya sering kali tidak berasarkan kompetesi yang dibutuhkan, (7) penataan sumber daya aparatur tidak disesuaikan dengan kebutuhan dan penataan kelembagaan birokrasi (Miftah Thoha, 2005:5).

Oleh karena itu permasalahan utama yang dihadapi organisasi pemerintah ini lebih pokus pada kinerja manajemen sumber daya manusia dalam menghadapi era disrupsi. Permasalahan kinerja manajemen sumber daya manusia di era desrupsi ini lebih ke arah perubahan mendasar dalam evolusi teknologi dan digitalisasi terutama inormasi yang dapat mengubah semua tatanan sumber daya manusia yang lebih mengenali mengenai keadaan sekarang yang banyak perubahan. Diterbitkannya Undang-Undang No 22 tahun 1999 dan semenjak reformasi ini, penataan pun dilakukan terhadap sumber daya manusia mengalami banyak perubahan, termasuk Undang-Undang No 32 tahun 2004 dan Undang-Undang No 5 tahun 2014, telah terjadi perubahan mendasar dalam penyelenggaraan dan penataan sumber daya manusia. Ini memberikan kekuatan dan kesempatan kepada instansi pemerintah untuk melakukan perbaikan dan pengembangan pelaksanaan pekerjaan dan hasil pekerjaan daripada organisasi melalui pendekatan strategik dan koheren untuk mengelola aset paling berharga milik organisasi dan orang-orang yang bekerja dalam organisasi baik secara individu maupun kolektif. Dalam hubungannya dengan era disrupsi (sedang terjadinya perubahan yang fundamental atau mendasar), hal ini tentu harus ada upaya untuk melakukan penataan kembali (right sizing) yang merupakan suatu kebutuhan mendesak untuk melihat seberapa jauh peta pelaksanaan pekerjaan dan hasil pekerjaan dalam manajemen sumber daya manusia organisasi serta diharapkan bisa berperan untuk menciptakan tata kepemerintahan yang baik. Melakukan penilaian terhadap sistem, prosedure dan proses pengelolaan sumber daya manusia, peta pelaksanaan pekerjaan dan hasil pekerjaan harus dilakukan dan diketahui supaya diperoleh suatu sistem yang kondusif terhadap perubahan yang ada. Melihat perbedaan karakteristik dari organisasi atau unit kerja yang ada dalam pemerintahan daerah di era disrupsi, maka kebutuhan peningkatan kinerja manajemen sumber daya mausia pun akan berbeda untuk masing-masing pegawai organisasi maupun unit kerjanya. Semakin kompleksnya problem dalam pengelolaan aparatur di daerah memunculkan berbagai pertanyaan tentang apa yang mesti dilakukan oleh pemerintah daerah dalam peningkatan profesionalisme aparatur. Jika kondisi ini tidak segera direspon dapat menimbulkan masalah yang semakin rumit dalam pelaksanaan pekerjaan manajemen sumber daya aparatur di daerah. 


\section{METODE}

Metode penelitian yang digunakan adalah metode penelitian kualitatif dengan pendekatan studi kasus observasi. Penggunaan metode kualitatif, karena masalah atau problem penelitian yang ingin digali memerlukan suatu eksplorasi untuk mendapatkan pemahaman yang mendalam atas suatu fenomena. Menurut Ndraha (2000 : 228) "melalui metode kualitatif peneliti mendengar dan melihat nara sumber berbicara sebenarnya (jangan dipengaruhi) tentang dirinya (mereka) sendiri sesuai dengan perspektif masing-masing". Menurut Poerwandari (2001:12), untuk mendapatkan pemahaman yang mendalam dan khusus atas suatu fenomena serta untuk dapat memahami manusia dalam segala kompleksitasnya sebagai makhluk subjektif, maka pendekatan kualitatif merupakan metode yang paling sesuai untuk digunakan. Sumber data dalam penelitian ini adalah data primer dan data sekunder.

\section{PEMBAHASAN}

\section{Kajian Empiris Penataan Sumber Daya Aparatur Pemerintah}

Penataan sumber daya manusia, dalam hal ini aparatur pemerintah telah mengalami perubahan sejak diterbitkannya Undang-Undang No 22/1999, Undang-Undang No 32/2004, dan Undang-Undang No 5/2014. Persoalan sumber daya aparatur pemerintah mulai dibenahi, namun karena banyak dan kompleknya persoalan di bidang kepegawaian maka pemecahan masalah kepegawaian kelihatan masih lambat, jumlah pegawai yang tidak poduktif, dan didukung kualitas yang kurang memadai, maka profesionalisme yang bekerja di pemerintahan dinilai banyak yang tidak kompeten. Menempatkan sejumlah lembaga yang bertangungjawab dalam melakukan penataan sumber daya aparatur pemerintah dapat dilihat dari peran dan fungsinya. Pelaksanaan pekerjaan penataan sumber daya aparatur pemerintah, seperti Badan Kepegawaian Negara bertugas menyelenggarakan manajemen pegawai negeri sipil yang mencakup perencanaan, pengembangan kualitas sumber daya pegawai negeri sipildan administrasi kepegawaian dan pengendalian, mendukung pumusan kebijakan kesejaheraan pegawai negeri sipil serta memberikan bimbingan teknis kepada unit organisasi yang menangani kepegawaian pada instansi pemerintah pusat dan daerah. Pelaksanaan pekerjaan Badan Kepegawaian Negara dalam menghindari tumpang-tindih kewenangan, telah memiliki fungsi secara jelas dan mampu menyelenggarakannya sesuai kebutuhan. Termasuk Lembaga Administrasi Negara turut bertanggungawab dalam pelaksanaan pekerjaan, terutama melaksanakan tugas pemerintahan di bidang administrasi negara tertentu sesuai dengan ketentuan perundang-undangan yang berlaku. Pelaksanaan pekerjaan yang ditampilkan lembaga ini lebih memiliki fungsi sebagai sebuah lembaga think-tank melalui hasil riset dan kajian aparatur negara, sekaligus memainkan fungsi dalam pengembangan sumber daya manusia aparatur negara melalui pendidikan dan pelatihan. Badan ini juga mempunyai kewenangan menyelenggarakan manajemen aparatur sipil negara, pengawasan dan pengendalian pelaksanaan norma, standar, prosedure, dan kriteria manajemen aparatur sipil negara. Demikian pula Badan Kepegawaian Daerah dalam pelaksanaan pekerjaannya lebih banyak mengurusi administrasi kepegawaian pemerintah daerah baik di pemerintah daerah kabupaten dan kota maupun pemerintah propinsi.

Pelaksanaan pekerjaan dan hasilnya daripada manajemen sumber daya aparatur pemerintah di daerah berdasarkan Undang-Undang No 5 tahun 2014, ternyata lebih menekankan pada upaya untuk mewujudkan aparatur sipil negara sebagai pofesi yang memiliki kewajiban mengelola dan mengembangkan dirinya dan wajib memertanggungjawabkan kinerjanya dan menerapkan prinsip merit dalam pelaksanaan manajemen aparatur sipil negara. Pelaksanaan pekerjaan dan hasilnya daripada manajemen sumber daya aparatur sipil negara di daerah yakni untuk menghasilkan pegawai aparatur sipil negara yang profesional, memiliki nilai dasar, etika profesi, bebas dari intervensi 
politik, bersih dari praktek korupsi, kolusi dan nepotisme, serta siap menghadapi era disrupsi. Adanya komisi aparatur sipil negara sebagai lembaga non struktural ternyata dapat turut membantu pelaksanaan pekerjaan dan hasilnya daripada manajemen sumber daya aparatur yang mandiri dan bebas dari intervensi pilitik untuk menciptakan pegawai aparatur siil negara yang profesional dan berkinerja, memberikan pelayanan secara asil dan netral serta mejadi perekat dan pemersatu bangsa. Komisi aparatur sipil negara turut mengibangi tuntutan di era disrupsi saat ini, karena memiliki tujuan utama dari komisi aparatur sipil negara antara lain ; (a) menjamin terwujudnya sistem merit dalam kebijakan dan manajemen aparatur sipil negara, (b) mewujudkan aparatur sipil negara yag profesional, berkinerja tinggi, sejahera, dan berfungsi sebagai perekat negara kesatuan republik indonesia, (c) mendukung penyelenggaraan pemerintahan negara yang efektif, efisien dan terbuka, serta bebas dari praktek korupsi, kolusi dan nepotisme, (d) mewujudkan pegawai aparatur siil negara yang netral dan tidak membedakan masyarakat yang dilayani bedasarkan suku, agama, ras dan golongan, (e) menjamin terbentuknya profesi aparatur sipil negara yang dihormati pegawainya dan masyarakatnya, (f) mewujudkan aparatur sipil negara yang dinamis dan berbudaya pencapain kinerja.

Fungsi maupun tugas komisi aparatur sipil negara turut menjaga dan memelihara keberlangsungan hidup seluruh organisasi pemerintah di masing-asing dadrah daerah pada saat memasuki era disrupsi. Fungsi komisi aparatur sipil negara berfungsi mengawasi pelaksanaan norma dasar, kode etik dan kode perilaku aparatur sipil negara, serta penerapan sistem merit dalam kebijakan dan manajemen aparatur sipil negara pada instansi pemerintah. Komisi aparatur sipil negara bertugas ; (a) menjaga netralitas pegawai aparatur sipil negara, melakukan pengawasan atas pembinaan profesi aparatur sipil negara, dan (c) melaporkan pengawasan dan evaluasi pelaksanaan kebijakan manajemen aparatur sipil negara. Dalam melaksanakan tugas tersebut, maka komisi aparatur sipil negara dapat melakukan beberapa kegiatan ; (a) menelusuri dta dan informasi terhadap pelaksanaan sistem merit dalam kebijakan dan manajemen aparatur sipil negara pada internal pemerintah, (b) melakukan pengawasan gerhadap pelaksanaan fungsi pegawai aparatur sipil negara sebagai pemersatu bangsa, (c) menerima laporan terhadap pelanggaran norma dasar serta kode etik dan kode perilaku pegawai aparatur sipil negara, (d) melakukan penelusuran data dan informasi atas prakarsa sendiri terhadap dugaan pelanggaran norma dasar serta kode etik dan kode perilaku pegawai aaparatur sipil negara, (e) melakukan upaya pencegahan pelanggaran noma dasar seta kode etik dan kode perilaku pegawai aparatur sipil negara. Dilihat dari pendekatan kelembagaan Lembaga Administriasi Negara dan Badan Kepegawaian Negara ternyata memiliki fungsi maupun tugas secara terinci diarahkan untuk mengimbangi kompleksitas masalah sumber daya aparatur pemerintah daerah di era disrupsi. Lembaga Administrasi Negara berfungsi ; (a) pengembangan standar kualitas pendidikan dan pelatihan, (b) pembinaan pendidikan dan peatihan kompetensi manajeial pegawai, (c) penyelenggaraan pendidikan dan pelatihan kompetensi secara sendiri mupun bersama, (d) pengkajian terkait kebijakan dan manajemen. Sedangkan tugasnya ; (a) meneliti, mengkaji dan melakukan inovasi manajemen sesuai kebutuhan kebijakan, (b) membina dan menyelenggarakan pendidikan dan pelatihan berbais kompetensi, (c) merencanakan dan mengawasi kebutuhan pendidikan dan pelatihan secara nasional, (d) meyusun standar dan pedoman penyelenggaraan pendidikan dan pelatihan, pelatihan teknis fungsional, dan pemberian akresitasi serta setifikat, (e) memberikan sertifikat keulusan peserta pendidikan dan pelatihan penjenjangan, (f) membina dan menhelenggaraan pendidika dan peatihan analisa kebijaka publik, (g) membina jabatan fungsional di bidang pendidikan dan pelatihan. Badan Kepegawaian Negara mempunyai fungsi ; (a) pembinaan penyelenggaraan manajemen, (b) penyelenggaraan manajemen dalam bidang pertimbangan tekni formasi, pengadaan , perpindahan antar instansi, persetujuan kenaikan pangkat dan pendun, (c) penyimpanan informasi 
pegawai yang telah dimutasikan oleh instansi pemerintah serta bertanggungjawab atas pengelolaan dan pengembangan informasi. Sedangkan tugasnya ; (a) mengendalikan seleksi calon pegawai, (b) membina dan menyelenggarakan penilaian kompetensi serta evaluasi pelaksanaan penilaian kinerja pegawai, (c) membina jabatan fungsional di bidang kepegawaian, (d) mengelola dan mengembangkan sistem informasi kepegawaian berbasis kompetensi didukung oleh sistem informasi kearsifan yang komprehensife, (e) menyusun norma, standar, dan prosedure kerja pelaksanaan kebijakan manajemen, (f) menyelenggarakan administrasi kepegawaian, (g) mengawasi dan mengendalikan pelaksaan noma, standar dan prosedure manajemen kepegawaian.

Dilihat dari pendekatan manajemen sumber daya manusia, dalam hal ini manajemen pegawai negeri sipil sesuai amanat UU No 5 thun 2014 menunjukkan bahwa pelaksanaan pekerjaan dan hasilnya meliputi ; (a) penyusunan dan penetapan kebutuhan, (b) pengadaan, (c) pangkat dan jabatan, (d) pengembangan karier, (e) pola karier, (f) promosi, (g) mutasi, (h) penilaian kinerja, (i) penggajian dan tunjangan, (j) penghargaan, (k) disiplin, (l) pemberhentian, $(\mathrm{m})$ jaminan pendiun dan jaminan hari tua, (n) perlindungan. Misalnya penilaian kinerja pegawai negeri sipil yang diselenggarakan oleh Pemerintah Daerah Propinsi Jawa Barat. Pemerintah Propinsi Jawa Barat memiliki Tim Penilai Kinerja PNS yang dibentuk melalui Keputusan Gubernur Jawa Barat No 800.05/Kep.710/BKD/2018 tentang Tim Penilai Kinerja PNS di Lingkungan Pemerintah Daerah Propinsi Jawa Barat. Tim tersebut dipimpin oleh Sekda Jabar. Pembentukan Tim Penilai Kinerja PNS itu sesuai dengan payung hukum dan perintah UU No 30/2014 tentang Administrasi, dan PP No 11/2017. Ada nama Baperjakat yang melakukan penilaian kinerja PNS, sekarang diganti dengan Tim Penilai Kinerja PNS Propinsi Jawa Barat yang beranggotakan ; Kepala Inspektorat, Kepala BKD, dan Kepala OPD sebagai Anggota Tidak Tetap. Kepala OPD dilibatkan untuk memahami aparat di dinas masing-masing. Misalnya, saat Tim menilai Dinas Marga dan Penataan Ruang Daerah, maka kepela OPD nya akan terlibat dalam Tim. Jika akan mengangkat pejabat administrasi atau dari staf mejadi eselon IV atau dari IV ke III sampai proses mutasi, maka kepala dinasnya ditugaskan khusus membahas dinasnya. Adanya Tim Penilai Kinerja PNS, maka pola pengangkatan atau mutasi jabatan di Pemerintah Daerah Propinsi Jawa Barat akan lebih baik, transparan dan adil. Tim Penilai Kinerja PNS ini telah menyusun aturan pola karier PNS yang akan menjadi pejabat selon II, III dan IV. Untuk syarat sertifikat pegadaan barang dan jasa, akan memudahkan yang berangkutan saat menjadi pejabat dalam melakukan pengadaan. Karena itu, mendorong PNS yang belum mengantongi sertifikat untuk mengikuti pelatihan. Jabatan juga akan disesuaikan dengan pendidikan dan keahlian, dimana kriteria ini kami tegaskan dalam penyusunan pola karier. Saat ini, Tim Penilai Kinerja PNS sedang memproses penentuan tiga posisi kepala biro yang berasal dari hasil lelang terbuka. Hasil lelang dan penunjukkan eselon II itu, sudah dilaporkan kepada pejabat Gubernur dan Kemendagri. Pola karier yang semakin jelas dan adanya Tim Penilai Kinerja PNS, akan didapatkan PNS yang mumpuni dan tidak ada pejabat yang nonjob serta kinerja Tim Penilai Kinerja PNS akan semakin sesuai dengan koridor hukum. Diupayakan untuk mendapatkan SDM yang berkualitas dan sesuai dengan persyaratan.

\section{Kajian Teoritis Kinerja Manajemen Sumber Daya Manusia}

Tingkat efekivitas manajemen sumber daya manusia dipandang turut mempengaruhi kinerja suatu organisasi, sebesar atau sekecil apa pun organisasi tersebut, hal ini seperti ditegaskan oleh Dave Ulrick (1997) bahwa " sumber daya manusia harus didefinisikan bukan dengan apa yang sumbe daya manusia lakukan, tetapi apa yang sumbe daya manusia hasilkan ". Pernyataan tersebut menunjukkan peningnya kinerja (pelaksanaan pekerjaan dan hasil pekerjaan) sumber daya manusia yang memiliki kemampuan untuk memilih sistem rancangan formal dalam suatu organisasi untuk 
menentukan efektivitas dan efisiensi terutama dilihat dari bakat sesorang untuk mewujudkan sasaran suatu organisasi. Menurut Roberth Mathis dan John Jackson (2001) menyatakan bahwa " karena sumber daya manusia dipandang semakin besar peranananya bagi kesuksesan suatu organisasi, maka banyak organisasi kini menyadai unsur manusia dalam organisasi dapat memberikan keunggulan besaing ". Pernyaaan tersebut mengandung arti bahwa manusia sebagai unsur sumbe daya manusia gelah mmberikan dan mempengaruhi kesukesan untuk melakukan persaingan antar organisasi dimasa yang akan datang. Oleh karena itu manajemen sumber daya manusia harus siap menghadapi tanangan dan perubahan yang semakin komplek dan sinamis serta meluas, hal ini banyak dipengaruhi oleh berbagai tanagan seperti ; perekonomian dan perkembangan teknologi, ketersediaan dan kualitas tenaga kerja, keendudukan dengan masalahya, serta restrukturisasi organisasi, bahkan tantangan yang lebih kompleks lagi di era desrupsi saat ini. Menurut Dave Ulrick (1997) menjelaskan bahwa " fokus utama dai manajemen sumer daya manusia adalah memberikan kontribusi pada suksesnya organisasi, dan kunci untuk meningkakan kinerja manajemen sumber daya manusia dalam organisasi adalah dengan memasikan aktivitas pelaskanaan pekerjaan suber daya manusia yang mendukung usaha organisas yang erpokus pada elemen berikut ini ;

a) Produktivitas. Diukur dari jumlah output per tenaga erja, peningkagan ganpa henti pada pouktivits telah menjadi kompetisi global/ poduktivitas tenaga kerja di sebuah organisasi dipengaruhi oleh usaha, program dan sistem manajemen.

b) Kualitas. Kualitas usatu barang mapun jasa akan sangat mempengaruhi kesuksesan jangka panjang organisasi. Jika suatu organisasi mempnyai reputasi menyediakan barang maupun jasa yang buruk kualitas, hal ini akan mengurangi perkembangan dan kinerja organisasi tersebut.

c) Pelayanan. Sumber daya manusia sring kali terlihat pada proses produksi barang atau jasa, manajemen sumbe daya manusia harus diikutsertakan pada saat merancang proses operasi. Pemecahan maslaah harus melibatkan semua karaan, tidak hanya manajer, diana proses tersebut sering kali membutuhkan perubahan pada budaya perusahaan, gaya kepemimpinan dan kebijakan dan praktek sumber daya manusia.

Untuk mencapai sasaran tersebu, manajemen sumber daya manusianharuslah terdiri dari aktivitas-aktivitas yang terkait, akan tetapi kinerja manajemen sumber daya manusia harus dalam kontek organisasi, serta para manajer sumber daya manusia harus mempertimbangkan faktorlingkungan, ekonomi, sosial, budaya dan teknologi. Faktor lingkungan ini sangatlah penting pada saat pelaksanaan pekerjaan (aktivitas) sumber daya manusia, seperti ; perencanaan dan analisis sumber daya manusia, kesetaaan kesempatan bekerja, rekruitmen atau kebutuhan tenaga kerja, pengembangan suber daya manusia, kompensasi dan keuntungan, kesehatan dan keselamatan serta keamanan, dan hubungan tenaga kerja. Kinerja manajemen sumber daya manusia harus tumbuh dan lebih siap dalam mengelola orang-orang dalam organisasi karena penggunaan orang dalam sebuah organisasi dapat menyediakan keunggulan kompetitif, baik domestik maupun internasional. Kinerja manajemen sumber daya manusia menekankan bahwa orang-orang di dalam organisasi adalah sumber daya manusia yang penting dan harus memainkan peran yag strategis serta pokus pada masalah-masalah serta implikasi yang sipatnya jangka panjang. Salah satu perubahan yang sangat penting di era disrupsi saat ini adalah menjadi pilihan dalam penekanan kinerja manajemen sumbe daya manusia, bahkan menurut Robert Mathis (2001) bahwa " seperti pelayanan pemerintahan atau sosial harus mengelola sumber daya manusia sebagai sesuatu yang berharga dan menjadi titik pusat usaha atau manajemen". Menurut Gomez Mejia, Balkin, dan Cardi (2007) menyatakan bahwa “ kinerja manajemen sumber daya manusia dalam suatu organisasi dapat dilihat dari betapa efektif produk dan bagaimana pelayanan organisasi diteruskan pada pelanggan. Sumber daya manusia pada 
suatu organisa adalah yang merancang, menghasilkan dan meneruskan pelayanan tersebut. Karenanya salah satu sasaran dari kinerja manajemen sumber daya manusia adalah menciptakan kegiatan yang meruakan kontribusi menuju superior organization performance “. Oleh karena itu sukesnya strategi suatu organisasi dalam meningkatkan kinerja manajemen sumber daya manusia ditempuh melalui beberapa pendekatan berikut ini ; keterlibatan dalam perencanaan strategis, pembuatan keputusan atas merger atau akuisi atau perampingan, mendesain ulang organisasi dan proses kerja, serta tanggungjawab keuangan sebagai hasil sumber daya manusia.

Kinerja manajemen sumber daya manusia berusaha mengukur kemajuan program atau aktivitas yang dilakukan oleh organisasi sektor publik dalam mencapai hasil. Kinerja manajemen sumber daya manusia menggunakan pendekatan sistematik untuk memperbaikin proses secara berkelanjutan dalam penetapan sasaran organisasi. Oleh karena itu kinerja manajemen sumber daya manusia lebih diarahkan pada ; prosees yang sistematik dalam organisasi, berusaha meperbaiki kinerja, prosesnya berkelanjutan dan berjangka panjang, penetapan sasaran kinerja strategik, mengukur kinerja, megumpulkan, menganalisis, menelaah dan melaporkan data kinerja, menggunakan untuk kepentingan perbaikan kinerja secara berkelanjutan. Seperti dalam pelaksanaan pekerjaan pengembangan pegawai dapat dilakukan melalui kegiatan non diklat melalui promosi, mutasi, diklat teknis atau fungsional dan diklat kepemimpina. Diklat ini dilakukan untuk meningkakan kompetensi teknikal, sementara diklat kepemimpia dilakukan untuk meningkatkan kompetensi manajerial. Termasuk pelaksanaan pekerjaan maajemen sumber daya manusia, seperti dalam penempatan pegawai masih diperlukan perbaikan dalam organisasinya. Kinerja manajemen sumber daya manusia berusaha untuk mengelola sumber daya paling penting dengan cara yang paling rasional, serta menekankan pada kebutuhan untuk mengelola orang dengan cara yang dapat menghasilkan nilai tambah dari mereka dan mencapai lingkungan yan kompetitif. Dalam hubungan ini, kinerja manajemen sumber daya manusia lebih menekankan pada beberapa aspek ;
a. Kepentingan manajemen
b. Mengadopsi pendekatan stratejik yang sangat terintegrasi dengan stategi khusus.
c. Mendapatkan nilai tambah dari orang-orang melalui proses pengembangan sumber daya manusia dan manajemen kinerja.

d. Kebutuhan akan busaya korporasi yang kuat, yang diekspresikan dalam pernyaaan visi dn misi serta diperbaiki atau diperkuat oleh proses komunikasi, pelatihan dan manajemen.

Menurut Michael Amsrong (2003) menyatakan bahwa " pelaksanaan pekerjaan daripada manajemen sumber daya manusia berkaitan pula dengan hubungan manusia, menekankan komunikasi, motivasi dan kepemimpinan. Memperlakukan orang seperti aset berharga, sumber keunggulan, kompetitif melalui komitmen, kemampuan beradaptasi, dan kualitas tinggi yang mereka miliki ". Oleh karena itu kinerja manajemen melihat karyawan, lebih sebagai alat daripada sasaran sehingga pendekatan kinerja ini menekankan kebutuhan untuk mendapatkan komitmen, hati dan pikiran melalui partisipasi aktif, komunikasi dan metode lain untuk mengembangkan organisasi dengan komitmen tingi, yang sangat dipercaya. Sedangkan menurut Trues (1977) menekankan pada sisi kepentingan manajemen, kepentingan karyawan. Dari uraian tersebut di atas menunjukkan bahawa kinerja manajemen sumber daya manusia harus berusaha menjaga, memelihara, dan melaksanakan dengan baik. Hal ini akan membantu dalam mempercepatan profesionalisme sumber daya manusia.

\section{Pentingnya Perbaikan Kinerja Manajemen Sumber Daya Manusia Di Era Disrupsi}

Di era disrupsi saat ini, ternyata semakin komplek, dinamis, serta penuh ketidakpastian yang dihadapi semua organisasi sehingga berusaha untuk melakukan upaya percepatan perbaikan secara 
menyeluuh dan proesional. Atas dasar inilah, dipelukan upaya percepatan profesionalisme sumber daya manusia, berikut ini ;

1) Memetakan gep kompetensi antara sumber daya manusianya. Pemerintah dapat mennggunakan kompetensi aparatur sipil negara dengan melakukan bancarking maka pemerintah akan memiliki pemerintah, serta jenis kompetensinya haus diperluas.

2) Mengidenifikasi jenis-jenis kompetesi yang sebaiknya diisi dengan non pns maupun melalui jalur P3K.

3) Mengembangkan program-program untuk pengembangan kompetensi dan pogram keoganisasian lainnya.

4) Menempakan sseorang dalam jabatan berdasarkan atas kesesuaian kompetensi.

5) Menempatkan seseorang dalam jabatan berdasarkan atas kesesuaian denan persyaatan bangsawan.

6) Menempatkan sesorang dalam jabatan berdasarkan atas kesesuaian kompetensi dengan persyaratan jahagan.

Upaya perbaikan kinerja maajemen sumber daya manusia merupakan sebuah tantangan yang harus dihadapinya dan harus berpijak pada arah kebijakan yang jelas membawa susunan yang baik dan jelas. Arah kebijakan yang jelas akan membawa penyusunan organisai perangkat daerah sesuai kebutuhan maupun maing-maasing. Dalam mengatur susunan organisasi dan kebutuhan jumlah kepegawaian yang disesuaikan dengan kebutuhan dan kemampuan daerah mang-masing sehingga prinsip rightsizing. Kemampuan daerah tersebut diatasi oleh kemampuan, seperti proses pengadaan dan penempaan pegawai di masing-masing satuan organisasi yang disusun berdasakan pada visi dan misi. Aspek struktur organisasi dan jumlah pegawai yang didasarkan pada prinsip-prinsip rightsizing yang sampai pada saat ini masih belum dilakukan, segera dianalisis dan ditata. Dalam organisasi pemerintah, perlunya pemahaman daerah tentang mengharmoniskan tiga pilar penopang keberhasilan mncapai tujuan organisasi yaitu visi, misi, penataan jumlah ogaisasi, jumlah dan kualitas sumber daya manusia, bahkan saat ini ada langkah yang harus diambil yaitu menyusun instrumen pendukung implemenasinya, menerapkan sistem promosi yang terbuka, berwawasan kebangsaan dan berbasis merit, pengembangan sistem penilaian kineja yang berorientasi pada hasil, menempakan kinerja manajemen bukan hanya sebagai masalah instrumental tetapi mencakup pengembangan budaya kerja dan sistem i sentif berbasis kinerja.

\section{KESIMPULAN}

Kinerja manajemen sumber daya manusia dalam organisasi di era diskrupsi, dan masalah kepegawaian merupakan masalah yang tidak pernah berhenti dan selalu timbul maalah-masalah baru. Hal ini dapat dimengerti, karena masalah kepegawaian adalah menyangkut hayat hidup manusia yang bekembang secara dinamis. Pengembangan kinerja manajemen sumber daya manusia hanya dapat dilakukan jika pemerintah menempatkan penilaian kinerja dalam perspektif yang luas, tidak hanya terbatas pada pembaharuan instrumental untuk penilaian kinerja. Pengemangan kinerja manajemen sumbe daya manusia membutuhkan adanya perbaikan insentif berbasis kinerja. Pemeintah perlu mendoong birokrasinya untuk secara terus menerus emperkuat sistem insentif yang dikembangkan supaya dapat menghargai kinerja aparatur secaa individual, termasuk pengembangan budaya kerja dengan cara memperbahaui nilai, simbul dan perilaku. 


\section{DAFTAR PUSTAKA}

Aminu, Tella, dan Mbaya. 2012. Public Policy Formulation and Implementation in Nigeria. Jurnal internasional Public Policy and Administration Research Vol.2, No.5

David, Fred. R. 2009. Strategic Management : Concepts. Alih Bahasa oleh Kresno Saroso. Prentice Hall. New Jersey.

Grindle, Merilee S. 1980. Politics and Policy Implementation in the Third World. New Jersey : Unity Press.

Goetsch, David L. dan Stanley B. Davis. 1997. Total Quality Management, diterjemahkan oleh Benyamin Molan. Total Kualitas Mana:iemen. Jakarta: Prenhallindo.Ndraha, Taliziduhu. 1999. Pengantar Teori Pengembangan Sumber Daya Manusia. Jakarta : Rineka Cipta.

Kluyver, C. A. \& Pearce II, J. A. 2006. Strategy: A View from the Top, 2nd Edition,. Upper Saddle River, NJ: Pearson Prentice Hall.

Luis E. Kurtz, Boone, David L. 2011. Pengantar Bisnis Kontemporer. Buku 2. Salemba Empat, Jakarta.

Messah dan Mucai. 2012. Factors Affecting the Implementation of Strategic Plans in Government Tertiary Institutions: A Survey of Selected Technical Training Institutes. Jurnal European Journal of Business and Management Vol 3, No.3.

Pearce II, John A. dan Robinson Richard B.Jr. 2003. Manajemen Strategis 10. Salemba Empat, Jakarta

Peraturan Bupati Sumedang Nomor 45 Tahun 2015 tentang Pelimpahan Sebagian Kewenangan Penandatanganan Perizinan dari Bupati kepada Kepala Badan Penanaman Modal dan Perizinan Terpadu (BPMPT) Kabupaten Sumedang .

Peraturan Daerah Nomor 9 Tahun 2014 tentang Pembentukan-Organisasi-Perangkat Daerah Kabupaten.

Poerwandari. 2001. Pendekatan Kualitatif dalam Penelitian Psikologi, Jakarta : Lembaga Pengembangan Sarana Pengukuran dan Pendidikan Psikologi.Fakultas Psikologi Universitas Indonesia.

Schwab, Klaus. 2018. The Global Competitiveness Report 2018. World Economic Forum.

Wahab, Solihin Abdul. 2008. Analisis Kebijakan, dari Formulasi ke Implementasi Kebijakan Negara. Jakarta : Bumi Aksara.

Watson, Gregory. 1996. Strategic Benchmarking. Jakarta : PT Gramedia.

Winarno, Budi. 2002. Teori dan proses Kebijakan Publik. Yogyakarta : Mediapress.

Wheelen, Thomas 1. Hunger, J.David. 2012. Manajemen Strategis, Edisi Kelima,. Andi,Yogyakarta 